\title{
The impact of climate change on ski season length and snowmaking requirements in Tyrol, Austria
}

\author{
Robert Steiger* \\ Institute of Geography, University of Innsbruck, Innrain 52, 6020 Innsbruck, Austria
}

\begin{abstract}
In this paper, the development and validation of a ski season simulation model (SkiSim 2.0) is described and results of the climate change assessment for 3 ski areas in Tyrol, Austria, are presented. The results of the validation process suggest that SkiSim 2.0 is an appropriate tool to simulate ski season lengths and snowmaking requirements at different altitudes and in different climatic subregions of the study area. Climate change impacts on ski season length are considerably less when incorporating snowmaking. All 3 modelled ski areas remain snow reliable until the 2040s (A1B) to the 2050s (B1). By then, current snowmaking technology has reached its technological limits. The required snow volume until the end of the century is projected to increase by up to $330 \%$. Although snowmaking is a suitable adaptation strategy for the next decades, it is unlikely to be a sustainable adaptation strategy beyond the middle of the century. Besides altitude, local climate characteristics clearly influence ski season length, requiring the use of localized climate data. A comprehensive study of the research area, modelling all ski areas, is needed to assess the vulnerability of the ski marketplace in Tyrol.
\end{abstract}

KEY WORDS: Climate change impacts $\cdot$ Ski season length $\cdot$ Snowmaking $\cdot$ Tyrol $\cdot$ Austria

\section{INTRODUCTION}

Most forms of tourism are linked to the natural environment and are, therefore, influenced by regional and local climate conditions (Becken \& Hay 2007). The Davos Declaration, a summary of the results of the Second International Conference on Climate Change and Tourism (Davos, Switzerland, 1-3 October 2007), identifies tourism as 'highly sensitive to the impacts of climate change' and calls on the tourism sector to 'rapidly respond to climate change' (UNWTO 2007, p. 2) by implementing 'climate-focused product diversification, to reposition destinations and support systems, as well as to foster all-season supply and demand' (UNWTO 2007, p. 3). Winter tourism in the Alps is characterized by a high dependency on snow and has been identified as highly vulnerable to climate change (Abegg et al. 2007), as snow is a very climatesensitive touristic resource.

For Switzerland, negative snow trends have been observed since the mid- to late-1980s (Laternser \& Schneebeli 2003, Marty 2008). Those stations below
$1300 \mathrm{~m}$ are especially affected, which can be mainly attributed to positive temperature trends (Scherrer et al. 2004). The $0^{\circ} \mathrm{C}$ isotherm in winter (Dec-Feb) moved up from $600 \mathrm{~m}$ in the $1960 \mathrm{~s}$ to $900 \mathrm{~m}$ in the $1990 \mathrm{~s}$ (Scherrer \& Appenzeller 2006). Hantel \& Hirtl-Wielke (2007) found that a $1^{\circ} \mathrm{C}$ warming in Austria is likely to shorten the snow season by about 1 mo (in Dec-Feb) at the altitude of maximum climate sensitivity $(\sim 700 \mathrm{~m})$. For the Pyrenees, a shortening of the snow season by around $50 \%$ was projected for the end of the century at $1500 \mathrm{~m}$ (B2 scenario, $+1.4^{\circ} \mathrm{C}$ ) to $2000 \mathrm{~m}$ (A2 scenario, $+3.1^{\circ} \mathrm{C}$ ) (López-Moreno et al. 2009).

Assessments of the impact of climate change on winter tourism exist for Canada, the US, the Alps, Sweden, Japan and Australia (for an overview, see Scott et al. 2008).

Supply-side studies of the ski tourism sector have traditionally employed 2 methodological approaches: empirical models and numerical models. In empirical models, statistical relationships between multiple variables relevant for ski season length are derived from climate station data. Abegg (Abegg 1996, Abegg et al. 2007), the first in Europe to deal with the impacts of cli- 
mate change on winter tourism, used the so-called '100-days rule'. This rule states that a ski area can only be operated successfully if a sufficient snow cover of $30 \mathrm{~cm}$ lasts for at least $100 \mathrm{~d}$ in 7 out of 10 seasons at the mean altitude of the ski area. Although it is not a strict rule but rather a working tool, it was confirmed by ski area operators and has been established as a standard definition for snow reliability (Scott et al. 2003). In the Alps, this rule was found to be fulfilled above $1050 \mathrm{~m}$ in the northern Alps, above $1200 \mathrm{~m}$ in the central Alps and above $1500 \mathrm{~m}$ in the southern Alps (Abegg et al. 2007). Currently, $91 \%$ of 666 analysed ski areas in the Alps can be considered as snow reliable. This proportion would drop to 75,61 and $30 \%$ in a 1,2 and $4^{\circ} \mathrm{C}$ warming scenario, respectively (Abegg et al. 2007). Although the methodology proved valuable for a sensitivity assessment on a province level, its applicability for individual winter destinations is limited, as the climatic classification is rather coarse.

Breiling et al. (1997) determined statistical relationships between temperature, precipitation and snow depth from 1965 to 1995 in Austria on a district level. Future snow depth was computed with a temperature increase of $2^{\circ} \mathrm{C}$ using the established statistical relationships. Average snow depths currently found at $1000 \mathrm{~m}$ were anticipated to shift upwards by 105 to $200 \mathrm{~m}$, depending on the district. The climate sensitivity of Austrian districts-ranging from minor to very strong without further explanation of these terms - was defined based on changes in snow depth and the economic importance of tourism. The warming since the 1980s was found to have had a minor to strong impact in the eastern part of Austria (lower Austria and Styria). Mid-term (by the 2020s) strong impacts were expected for the southern parts (Carinthia) and very strong impacts for Kitzbuehel eastwards to Salzburg and upper Austria. Long-term (by the 2050s) very strong impacts were expected for western Austria (Vorarlberg, Tyrol), where the highest ski areas are situated and dependency on tourism is very high.

In numerical models, the snowpack is computed by multiple climate variables. The models differ in their temporal resolution and complexity. Although more complexity requires more climate variables, less complex models entail the risk of oversimplification as more processes need to be parameterized. Steiger (2007) and Steiger \& Mayer (2008) used a simple degree-day model to assess the suitability of snowmaking as an adaptation strategy for ski areas in the Bavarian Alps (Germany) and Tyrol (Austria). Although, under present climate conditions, the line of technical snow reliability was found to be at $1000 \mathrm{~m}$, a warming of $2^{\circ} \mathrm{C}$ raised that line to $1500-1600 \mathrm{~m}$.

Scott et al. (2003) used a locally calibrated temperature-index model, with daily temperature and precipi- tation as input variables. This model (SkiSim 1.0) was the first to incorporate snowmaking as a climate change adaptation strategy and derived operational decisions from interviews with ski area managers. Scott et al. (2003) found that the projected shortening of the ski season in central Ontario (Canada) was significantly less than in preceding studies that did not consider snowmaking.

Although 'the multinational research literature on climate change and skiing is perhaps the best developed in the tourism sector' (Scott 2006, p. 55), several shortcomings have been identified. Snowmaking has become standard for ski areas in many regions, but it has not been considered in the majority of studies (but see Hennessy et al. 2003, Scott et al. 2003, 2008, Steiger 2007, Steiger \& Mayer 2008). In most studies, the simulations were conducted for only a single altitude of the ski area (e.g. the base of ski runs or a mid-point), neglecting the importance of altitude. Finally, as the magnitude of climate change varies in different regions of the world, it is necessary to use transferable models to be able to compare potential vulnerability.

Thus, the objective of the present study was to apply the SkiSim model (Scott et al. 2003) on ski areas in Tyrol (Austria) and to further develop the modelhereafter referred to as SkiSim 2.0-to assess the impact of climate change on the vulnerability of winter destinations. As snow depth can change rapidly with altitude and as the ski areas often have altitude differences of $1000 \mathrm{~m}$ or more, the model was designed to simulate snowpack and snowmaking requirements at $100 \mathrm{~m}$ altitudinal bands at each ski area. The study area and chosen test sites are presented in the next section followed by the model setup and validation process (Section 3) and results of the climate change impacts assessment (Section 4).

\section{STUDY AREA}

Tourism is an important economic factor in Tyrol directly contributing about $15 \%$ to the gross domestic product (Tirol Werbung 2010). The winter season is dominant ( $60 \%$ of annual overnight stays) and skiing is the number one touristic product, generating 27 million skier days (MANOVA 2009). Mean annual precipitation is highly variable, ranging from $657 \mathrm{~mm}$ (Prutz, $870 \mathrm{~m}$ ) to $1886 \mathrm{~mm}$ (Jungholz, $1060 \mathrm{~m}$ ). An application of the 100-days rule on 52 climate stations revealed that the $1200 \mathrm{~m}$ line for snow reliability cannot be confirmed for the 1981/1982-2000/2001 period (Fig. 1). Furthermore, the great differences between stations at similar altitudes show that a uniform altitudinal line for snow reliability cannot be defined for Tyrol. 


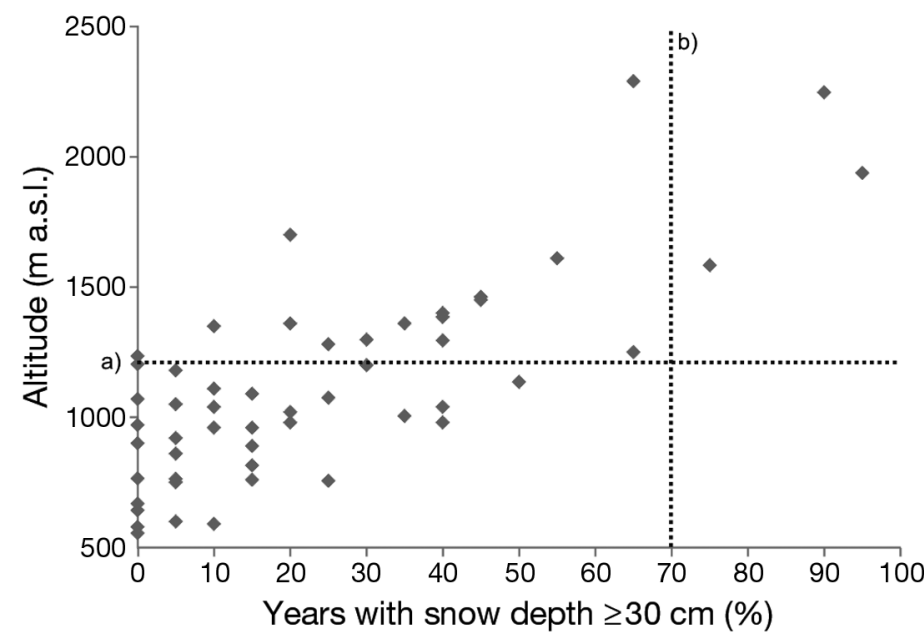

Fig. 1. Relative number of winters with a snow depth $\geq 30 \mathrm{~cm}$ for $\geq 100 \mathrm{~d}$, at 52 climate stations in Tyrol (1981/19822000/2001). Line (a) marks $1200 \mathrm{~m}$, the assumed line of snow reliability in Tyrol (Abegg et al. 2007). Line (b) marks the 100 -days in 7 out of 10 winters threshold

Large-scale effects, such as decreasing precipitation from the northern fringe of the Alps to the inner parts, as well as small-scale effects, such as orographic features or frequent Foehn effects, are responsible for this high spatial variability (Fliri 1975), requiring localized climate data.

Three climate stations and ski areas were chosen to test model performance and climate change impacts. The selection criteria for climate stations were a consistent data set and differing amounts of precipitation (drier/wetter regions). Ski areas were chosen based on their mean altitude to represent a low-, mid- and highaltitude ski area, and their proximity to a climate station (Tables 1 \& 2).

\section{METHODOLOGY}

The methodological framework is provided in Fig. 2, a description of the procedures and data sources is presented in the remainder of this section. Daily temperature and precipitation are the required variables for the snow model in SkiSim 2.0. Additionally, daily snowfall or snow depth is required for the calibration and validation process. A dense network of stations in the research area allowed the consideration of regional climate characteristics. The data were provided by the hydrological service of Tyrol (Hydrographischer Dienst Tirol) and by the Central Institute of Meteorology and Geodynamics (ZAMG).

In the natural snow model, snow accumulation and snowmelt are calculated (Section 3.1) and results are validated with measured snowfall sums and snow cover days (Section 3.5). In the snowmaking module
(Section 3.2), snow is produced, being restricted by snowmaking dates, technological limits and decisionmaking (e.g. stop production when enough snow is produced), and added to the snowpack. Temperature and precipitation are extrapolated to $100 \mathrm{~m}$ elevation bands (Section 3.4) and the natural snow model and snowmaking module are run for each altitudinal band. The resulting ski season length, including snowmaking based on station data, is validated with ski operation statistics (Section 3.5). For the climate change impact assessment, monthly change signals for temperature and precipitation are downscaled to each climate station using a stochastic weather generator (LARS-WG), producing daily time series required as input into SkiSim 2.0 (Section 3.3).

\subsection{Natural snow model}

The snow water equivalent (SWE) of the snowpack $\left(\mathrm{SWE}_{\text {pack }}\right)$ is calculated on a daily basis (Eq. 1)

$$
\mathrm{SWE}_{\mathrm{pack}}=\mathrm{SWE}_{\mathrm{pack}(t-1)}+\mathrm{SWE}_{\mathrm{S}}-M
$$

where $\mathrm{SWE}_{\mathrm{S}}$ is the SWE of fresh snow (Eq. 2), $t$ is the timestep and $M$ is melt (Eq. 6). The snow model of SkiSim 1.0 was replaced in order to (1) consider temporally variable melt factors, (2) consider a delayed melt due to the difference of snowpack and air temperature, and (3) calibrate snowfall temperature differently as no information on the SWE of fresh snow was available in the research area. A new snow model was built combining several components from existing snow model literature as described in the next sections.

\subsubsection{Snow/rain event classification}

Critical temperature thresholds $\left(T_{\mathrm{c}, \min }\right.$ and $\left.T_{\mathrm{c}, \max }\right)$ were calibrated with snowfall data for each climate station separately (Section 3.5). If the mean temperature $\left(T_{\text {mean }}\right)$ is below $T_{\mathrm{c} \text {,min }}, 100 \%$ of precipitation $(p)$ occurs as snow; if it is above $T_{\mathrm{c}, \max }, 100 \%$ of precipitation occurs as rain. In between, the snow/rain ratio is interpolated linearly

$$
\mathrm{SWE}_{\mathrm{S}}=p \frac{T_{\mathrm{c}, \max }-T_{\text {mean }}}{T_{\mathrm{c}, \max }-T_{\mathrm{c}, \min }}
$$

where $T_{\mathrm{c}, \min }<T_{\mathrm{c}, \max }$ and $p$ is precipitation (mm).

For the validation process, the $\mathrm{SWE}_{\mathrm{S}}$ is converted to $\mathrm{cm}$ with density $\left(\rho_{\mathrm{S}}\right)$ calculated as a function of temperature (Meister 1986):

$$
\rho_{\mathrm{S}}=545\left(5-T_{\text {mean }}\right)^{-1.55}+50
$$

where the mean temperature $\left(T_{\text {mean }}\right)$ is $\leq 3^{\circ} \mathrm{C}$ (Meister 1986). 
Table 1. Characteristics of 3 ski areas. Letters A, B, C correspond to climate stations 1, 2, 3, respectively, in Table 2

\begin{tabular}{|llrcrc|}
\hline $\begin{array}{l}\text { Ski } \\
\text { area }\end{array}$ & Location & $\begin{array}{r}\text { Elevation } \\
\text { range }(\mathrm{m})\end{array}$ & $\begin{array}{c}\text { Mean altitude } \\
\text { of ski slopes } \\
(\mathrm{m})\end{array}$ & $\begin{array}{c}\text { No. } \\
\text { ski lifts }\end{array}$ & $\begin{array}{c}\text { Distance to } \\
\text { climate station } \\
(\mathrm{km})\end{array}$ \\
\hline A & St. Johann & $668-1605$ & 1100 & 13 & 1 \\
B & Patscherkofel & $903-2247$ & 1500 & 5 & 6.5 \\
C & Zillertal Arena & $1259-2502$ & 1900 & 35 & 0.5 \\
\hline
\end{tabular}

Table 2. Characteristics of 3 climate stations. Mean winter precipitation and temperature are from Nov-Apr 1981-2000. Numbers 1, 2, 3 correspond to ski areas A, B, C, respectively, in Table 1

\begin{tabular}{|c|c|c|c|c|c|c|}
\hline $\begin{array}{l}\text { Climate } \\
\text { station }\end{array}$ & Location & $\begin{array}{l}\text { Altitude } \\
(\mathrm{m})\end{array}$ & $\begin{array}{l}\text { Mean winter } \\
\text { precipitation } \\
(\mathrm{mm})\end{array}$ & $\begin{array}{c}\text { Mean winter } \\
\text { temperature } \\
\left({ }^{\circ} \mathrm{C}\right)\end{array}$ & $\begin{array}{l}\text { Lat. } \\
\mathrm{N}\end{array}$ & $\begin{array}{l}\text { Long. } \\
\text { E }\end{array}$ \\
\hline 1 & St. Johann & 756 & 741 & 0.8 & $47^{\circ} 31^{\prime}$ & $12^{\circ} 26^{\prime}$ \\
\hline 2 & Innsbruck & 579 & 316 & 3.3 & $47^{\circ} 15^{\prime}$ & $11^{\circ} 20^{\prime}$ \\
\hline 3 & Gerlos & 1250 & 426 & -1.4 & $47^{\circ} 13^{\prime}$ & $12^{\circ} 02^{\prime}$ \\
\hline
\end{tabular}

\subsubsection{Melt}

In temperature-index models, potential melt $\left(M_{\text {pot }}\right)$ is defined as the product of the mean temperature and a degree day factor (ddf), if temperature is above a critical threshold-usually set at $0^{\circ} \mathrm{C}$

$$
M_{\text {pot }}=\operatorname{ddf} \times T_{\text {mean }}
$$

if $T_{\text {mean }}>0^{\circ} \mathrm{C}$.

As the melt factor increases in the course of the season due to the changing quality of the snow and the increasing incoming radiation (Martinec 1960, Kustas et al. 1994), a variable degree-day factor following a sinusoidal increase from 21 Dec to 21 Jun (Braun \& Aellen 1990) was implemented in the model. The minimum $\left(\mathrm{ddf}_{\min }\right)$ and maximum $\left(\mathrm{ddf}_{\max }\right)$ boundaries were calibrated based on the variance of measured and

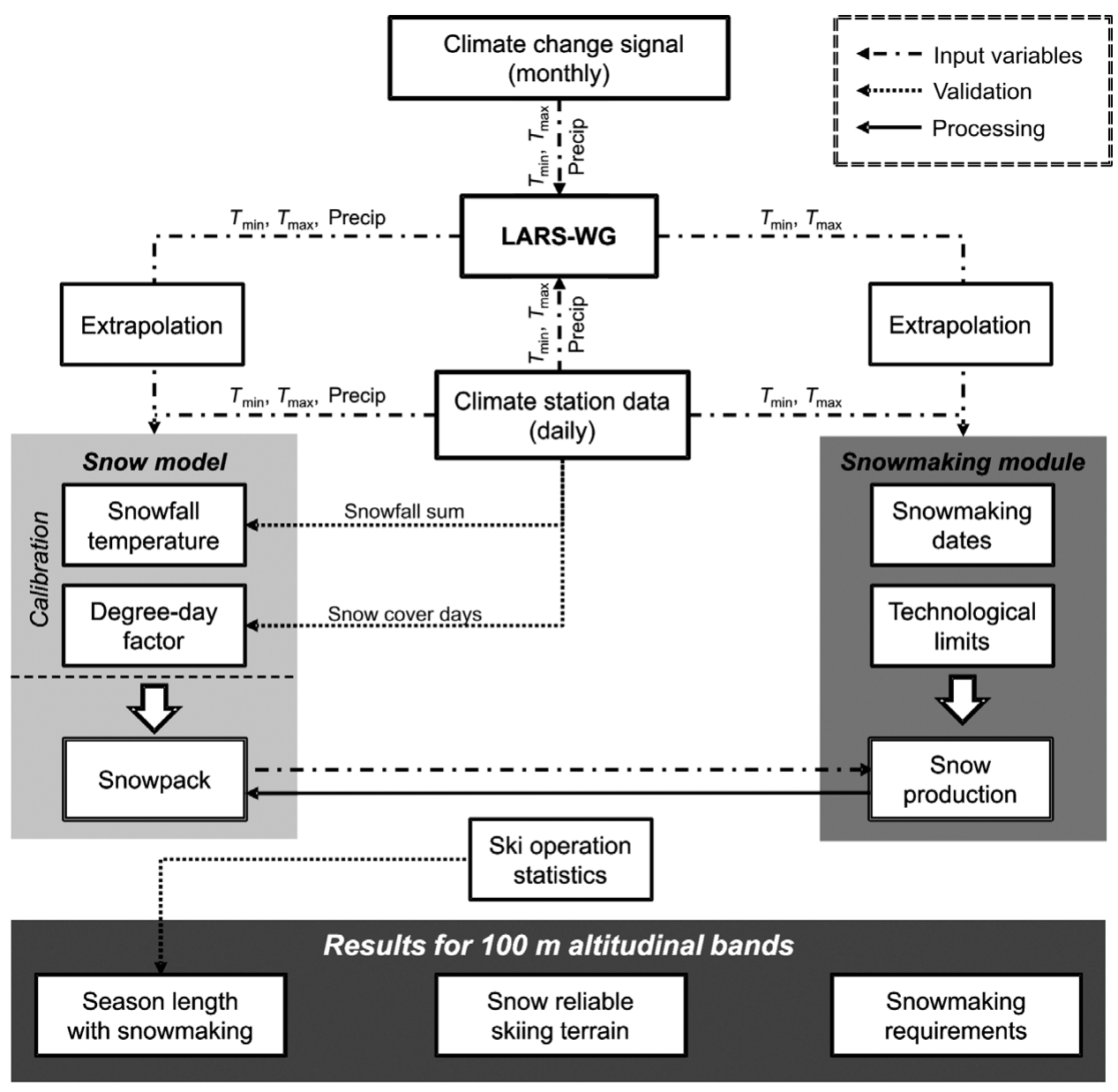

Fig. 2. Methodological framework of SkiSim 2.0 (adapted from Scott et al. 2003) 
modelled snow cover days (SWE $\geq 5 \mathrm{~mm}$ ) (Section 3.5). Snowmelt occurs if the temperature of the snowpack $\left(T_{\text {pack }}\right)$ is raised to the isothermal condition at $0^{\circ} \mathrm{C}$. Hence, melt is delayed depending on the difference between the snowpack temperature and the mean air temperature (Brooks et al. 2003). In SkiSim 2.0, the snowpack temperature equals the mean temperature of the previous day, if $T_{\text {mean }} \leq 0^{\circ} \mathrm{C}$. The cold content of the snowpack $\left(\mathrm{CC}_{\text {pack }}\right)$ defines the amount of energy that is needed to heat the snowpack to $0^{\circ} \mathrm{C}$, thus leading to effective snow melt (Brooks et al. 2003)

$$
\mathrm{CC}_{\text {pack }}=\frac{\mathrm{SWE} \times T_{\text {pack }}}{160}
$$

Effective melt $(M)$ is calculated as follows, if $M_{\text {pot }}-$ $\mathrm{CC}_{\text {pack }}>0$ :

$$
M=M_{\text {pot }}-\mathrm{CC}_{\text {pack }}
$$

\subsection{Snowmaking module}

The parameters of SkiSim 1.0 (Scott et al. 2003) were confirmed in interviews with ski area managers of the research area (Table 3 ). While the technological limits (temperature threshold and capacity) and the constant snowpack density to simulate ski slope grooming were adopted, the operational decisions to produce snow were improved. The snowmaking season dates are regulated by law. Before and after these dates, the snowmaking module is set inactive. As soon as temperatures are sufficient, snow is produced until a snow depth of $30 \mathrm{~cm}$ is reached. This represents the 'baselayer snowmaking' that is applied to all altitudinal bands, regardless of natural snowfall. The goal is to have a sufficiently dense and resistant snow cover and to be able to realize scheduled season openings (Steiger \& Mayer 2008). After base-layer snowmaking is finished, 'improvement snowmaking' starts, assuring a continuous ski operation until the scheduled end of the season. The ski area managers' experience on the amount of machine-made snow required to stay in operation until the Easter holidays is represented by the calibration of a critical snow depth for each altitu- dinal band. If modelled snow depth falls below the threshold, snow is produced until the snow depth meets the minimum operational threshold again. Snow production is calculated on an hourly basis by linearly interpolating temperatures between $T_{\min }$ and $T_{\max }$.

\subsection{Climate change scenarios}

Regional climate model data (REMO) were provided by the Max Planck Institute for Meteorology in Hamburg, Germany, and processed at the Institute of Meteorology at University Freiburg. REMO has a resolution of $0.088^{\circ}(10 \times 10 \mathrm{~km})$ and is nested in the global circulation model (GCM) ECHAM5/MPI-OM. Compared to other RRR CCC models (RCMs) of the PRUDENCE experiments, REMO is slightly warmer over the Alps in winter (Dec-Feb) than the ensemble mean and cooler in the other seasons (Christensen \& Christensen 2007). REMO produces more precipitation than the ensemble mean in winter and summer and is within the ensemble mean in spring and autumn (Christensen \& Christensen 2007). Change signals for seven 30 yr periods $(2010-2039,2020-2049,2030-$ 2059, 2040-2069, 2050-2079, 2060-2089 and 20702099) compared to the baseline climate 1971-2000 under 2 different greenhouse gas emission scenarios (A1B and B1) were derived for temperature and precipitation.

Temperature and precipitation changes were averaged over 9 grid cells as recommended by the data distribution centre. A stochastic weather generator (LARS-WG v.5.11) was used to downscale the $30 \mathrm{yr}$ change signals to each climate station (Semenov \& Barrow 1997). LARS-WG derives a set of parameters for probability distributions of weather variables $\left(T_{\min }\right.$, $T_{\max }$ precipitation, length of dry and wet spells and standard deviation of temperature) from observed daily data. With this set of parameters synthetic weather time series can be generated by a random selection of values from the appropriate distributions (Semenov \& Stratonovitch 2010).

Table 3. Parameters of the snowmaking module

\begin{tabular}{|lll|}
\hline Parameter & Value & Source \\
\hline Minimum snow depth for a skiable day & $30 \mathrm{~cm}$ & Interviews, Abegg (1996), Scott et al. (2003) \\
Snowpack density on a ski slope & $350 \mathrm{~kg} \mathrm{~m}^{-3}$ & Fauve et al. (2002), Scott et al. (2003) \\
Snowmaking season dates & $1 \mathrm{Nov}-31 \mathrm{Mar}$ & Interviews \\
Temperature threshold for snowmaking & $-5^{\circ} \mathrm{C}$ & Interviews, Scott et al. (2003) \\
Base layer snowmaking & $30 \mathrm{~cm}$ & Interviews, Steiger \& Mayer (2008) \\
Improvement snowmaking & Calibrated for each & Interviews, Steiger \& Mayer (2008) \\
Snowmaking capacity & altitudinal band & Interviews, Scott et al. (2003) \\
(calculated on an hourly basis) & $10 \mathrm{~cm} \mathrm{~d}^{-1}$ & \\
\hline
\end{tabular}


Table 4. Derived temperature lapse rates $\left({ }^{\circ} \mathrm{C} 100 \mathrm{~m}^{-1}\right.$ ) for dry and wet days (precipitation $<1 \mathrm{~mm}$ and $\geq 1 \mathrm{~mm}$, respectively). Lapse rates on wet days did not differ between stations

\begin{tabular}{|c|c|c|c|c|c|c|c|c|c|c|c|c|}
\hline \multirow[b]{2}{*}{ Station (altitude) } & \multirow[b]{2}{*}{1} & \multirow[b]{2}{*}{2} & \multirow[b]{2}{*}{3} & \multirow[b]{2}{*}{4} & \multirow[b]{2}{*}{5} & \multicolumn{2}{|c|}{ - Month - } & \multirow[b]{2}{*}{8} & \multirow[b]{2}{*}{9} & \multirow[b]{2}{*}{10} & \multirow[b]{2}{*}{11} & \multirow[b]{2}{*}{12} \\
\hline & & & & & & 6 & 7 & & & & & \\
\hline \multicolumn{13}{|l|}{ Dry days } \\
\hline St. Johann-Ehrenbachhöhe (756-1760 m) & 0.1 & 0.1 & 0.4 & 0.6 & 0.6 & 0.6 & 0.6 & 0.5 & 0.5 & 0.3 & 0.2 & 0.1 \\
\hline Innsbruck-Patscherkofel (579-2247 m) & 0.2 & 0.4 & 0.6 & 0.7 & 0.7 & 0.7 & 0.6 & 0.6 & 0.6 & 0.5 & 0.4 & 0.3 \\
\hline Gerlos-Innerschmirn (1250-1610 m) & 0.3 & 0.3 & 0.4 & 0.4 & 0.5 & 0.5 & 0.4 & 0.4 & 0.3 & 0.3 & 0.2 & 0.1 \\
\hline \multicolumn{13}{|l|}{ Wet days } \\
\hline All stations & 0.3 & 0.5 & 0.6 & 0.7 & 0.7 & 0.7 & 0.6 & 0.6 & 0.5 & 0.5 & 0.4 & 0.3 \\
\hline
\end{tabular}

\subsection{Extrapolation of temperature and precipitation}

Three additional climate stations were used to derive temperature and precipitation lapse rates for each study site. The mean lapse rate for precipitation was $3 \% 100 \mathrm{~m}^{-1}$. Owing to frequent cold air pools, it turned out to be useful to differentiate the temperature lapse rates for dry (precipitation $<1 \mathrm{~mm}$ ) and wet (precipitation $\geq 1 \mathrm{~mm}$ ) days (Table 4 ). Very frequent and persistent conditions with temperature inversions caused a low lapse rate at climate station St. Johann from November to February, being less pronounced at stations Innsbruck and Gerlos. The lapse rates on wet days did not differ between the stations and ranged from $0.4^{\circ} \mathrm{C} 100 \mathrm{~m}^{-1}$ in December and January to $0.6^{\circ} \mathrm{C}$ $100 \mathrm{~m}^{-1}$ from July to September.

\subsection{Calibration and model validation at 3 study sites}

An even number of years were chosen for the calibration (1981/1982-1989/1990) and validation period (1990/1991-1998/1999), with both snow-poor and snowabundant winter seasons (Fig. 3). Snowfall temperature $\left(T_{\mathrm{c}, \min }, T_{\mathrm{c}, \max }\right)$ was calibrated based on the variance of modelled versus measured accumulated snow in the calibration period (Table 5).

Snowfall sum was simulated well in the calibration and validation period, except at station Gerlos in the calibration period. Model performance was equal in snow-poor and snow-abundant seasons (Fig. 3). When modelling with data produced by the weather generator, annual differences were small (Innsbruck $\mathrm{R}^{2}=$ 0.92, St. Johann $\mathrm{R}^{2}=0.96$, Gerlos $\mathrm{R}^{2}=0.97$ ). The performance of SkiSim 2.0 for multi-year averages (1981/1992-1998/1999) being relevant for the climate change impact assessment is fair for snowfall, although using LARS-WG data clearly overestimated snowfall at the low-altitude stations Innsbruck and St. Johann (Table 5).

The number of snow cover days ( $\mathrm{SCD} ; \mathrm{SWE} \geq 5 \mathrm{~mm}$ ) was modelled well in both periods, except at Gerlos in the validation period (Table 5). Model performance was equal in snow-poor and snow-abundant years, with a tendency to slightly overestimate SCD at St. Johann and Gerlos (Fig. 4). The length of the snow season modelled with LARS-WG data showed no significant difference to model runs with measured data (Innsbruck $\mathrm{R}^{2}=$ 0.96 , St. Johann $\mathrm{R}^{2}=0.97$, Gerlos $\mathrm{R}^{2}=0.91$ ). The difference of multi-year averages was within an acceptable range $(<5 \%$ of mean measured SCD) at St. Johann and Gerlos and was underestimated by $10 \%$ at Innsbruck when using LARS-WG data (Table 5).

The validation of the entire model, including the snowmaking module, was completed through comparison of reported versus modelled season lengths (snow depth $\geq 30 \mathrm{~cm}$ ) over an 8 to $12 \mathrm{yr}$ time period, depending on the introduction of snowmaking facilities at the 3 ski areas. Data on the number of operation days were taken from the annual railway statistics. Ski areas A and B start the season when snow conditions are sufficient and terminate it on Easter Monday owing to reduced demand. Ski area C usually does not open before the first days of December and closes the weekend after Easter Monday. Thus the modelled ski season was restricted to these individual opening and closing dates in the validation process. The modelled

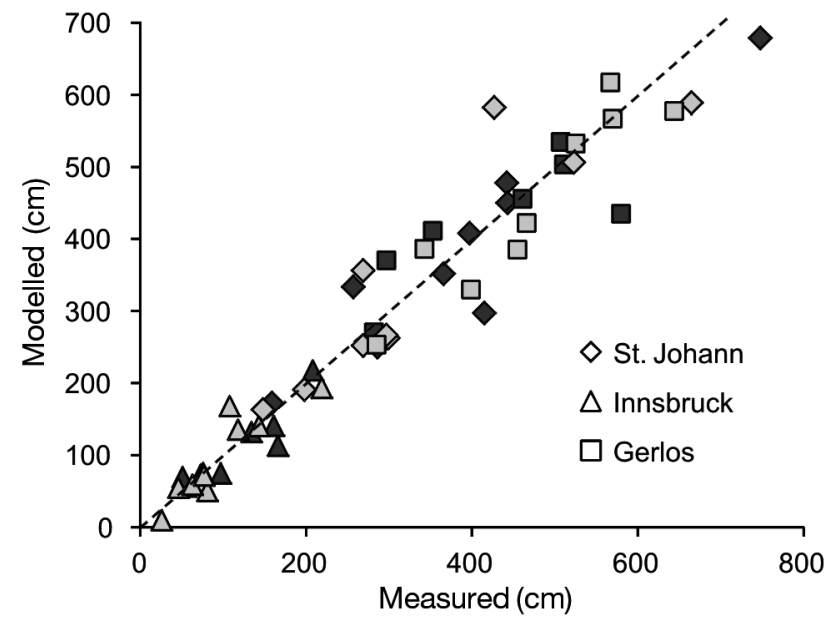

Fig. 3. Measured versus modelled annual snowfall sums (dark grey: 1981/1982-1989/1990, light grey: 1990/1991-1998/1999 
average ski season length at all study areas deviate by only $1 \mathrm{~d}$ from reported ski season lengths (Table 5).

It can be concluded that the performance of SkiSim 2.0 is sufficient for climate change impact assessments analysing changes in multi-year averages.

\subsection{Climate change assessment approach}

Several uniform pre-conditions were defined to allow a comparison of results of the study sites. In contrast to the validation process, individual opening and closing dates were not considered in the climate change assessment, thus producing comparable potential ski season lengths. Hence, the calculated season lengths in the climate change assessment are different from the season lengths of the validation process.

As no official statistics on the ski areas' snowmakingcoverage and capacity were available, a snowmaking coverage of $100 \%$ was assumed, which, based on interviews and the survey of Wolfsegger et al. (2008), most Austrian ski areas aim to reach in the future. Currently, about $75 \%$ of the ski slopes in Tyrol are covered by snowmaking (Fachverband Seilbahnen Österreichs pers. comm.). A weighted average of modelled snow production was calculated based on the altitudinal distribution of ski slopes to represent a mean value of the entire ski area:

Produced snow $=\sum_{i=1}^{n}$ tsnow $_{i} \times \propto_{i}$, with $\propto_{i}=\frac{A i}{A}$

where tsnow $w_{i}$ is technically produced snow, $\propto_{i}$ is the weighting factor composed of the total ski slope area (A) and the ski slope area in the individual elevation band $\left(A_{i}\right)$, and $i$ is the altitudinal band.

A potential development of snowmaking technology is regarded in a second variable (snow required). If the modelled season length with current snowmaking technology is less than $100 \mathrm{~d}$, the required amount of additional technical snow to reach $100 \mathrm{~d}$ is calculated without any temperature or capacity limits. Such temperature-independent snow production has already been introduced at 2 glacier ski areas in Austria (Pitztal, in 2009) and Switzerland (Zermatt, in 2008).

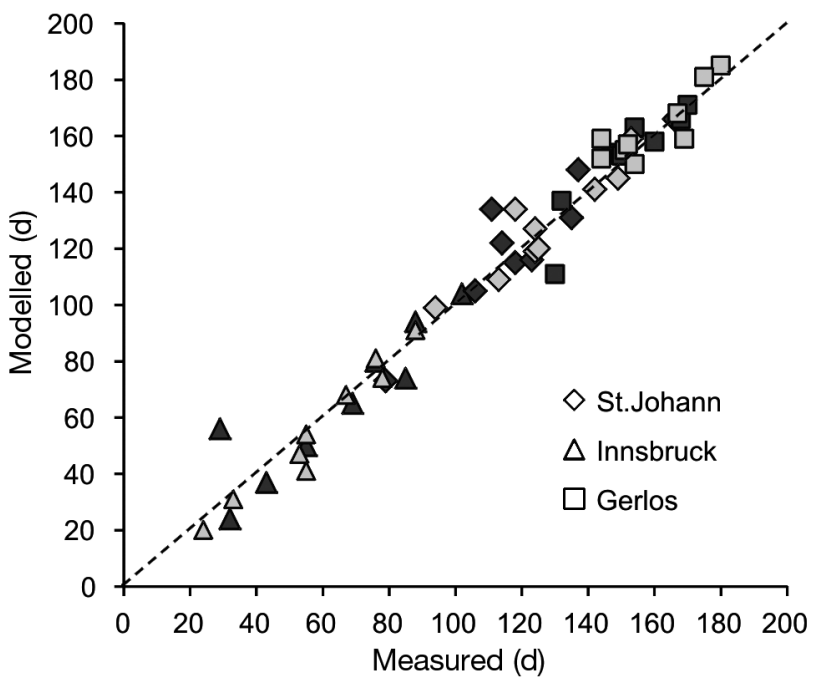

Fig. 4. Measured versus modelled annual snow cover days (dark grey: 1981/1982-1989/1990, light grey: 1990/1991-1998/1999)

\section{RESULTS}

\subsection{Climate change signal}

Although projected temperature changes in the winter half-year (Nov-Apr) were similar at all 3 stations, precipitation changes were different, with the lowest increases at Station C (Table 6). Modelled natural SCD at the altitude of the climate stations declined by 2 to $3 \mathrm{wk}$ in the 2030s, by 4 to $7 \mathrm{wk}$ in the 2050s and by 8 to $14 \mathrm{wk}$ in the 2080s.

\subsection{Impact on ski season length}

Applying the 100-days rule at the mean altitudes of the ski areas, ski area A is naturally snow reliable until the 2020s (A1B) to the 2030s (B1) (Fig. 5). Incorporating snowmaking, 100 operation days can be ensured until the 2050s to the 2070s. Still incorporating snowmaking, short-term losses (by the 2030s) of skiable days are $0-8 \%$, medium-term losses (by the 2050s) are $9-24 \%$ and long-term losses (by the 2080s) are $32-90 \%$. Ski

Table 5. Performance of SkiSim 2.0. Calib.: calibration period, Valid.: validation period. For multi-year averages, snow cover and snowfall are means. Meas: measured, Mod: modelled, LARS: modelled with LARS-WG data, Rep.: reported

\begin{tabular}{|c|c|c|c|c|c|c|c|c|c|c|c|c|c|c|}
\hline \multirow[b]{3}{*}{ Station } & \multirow[b]{3}{*}{$\begin{array}{c}T_{\mathrm{c}, \text { min }}- \\
T_{\mathrm{c}, \text { max }}\left({ }^{\circ} \mathrm{C}\right)\end{array}$} & \multirow[b]{3}{*}{$\underset{\mathrm{ddf}_{\min }-}{\mathrm{ddf}_{\max }}$} & \multicolumn{4}{|c|}{ Single year -} & \multicolumn{6}{|c|}{ Multi-year averages (1981/1982-1998/1999) } & \multirow{2}{*}{\multicolumn{2}{|c|}{$\begin{array}{l}\text { Ski season } \\
\text { length (d) }\end{array}$}} \\
\hline & & & \multicolumn{2}{|c|}{$\mathrm{R}^{2}$ snowfall } & \multicolumn{2}{|c|}{$\mathrm{R}^{2}$ snow cover } & \multicolumn{3}{|c|}{ Snow cover $(\mathrm{d})$} & \multicolumn{3}{|c|}{ Snowfall $(\mathrm{cm})$} & & \\
\hline & & & Calib. & Valid. & Calib. & Valid. & Meas. & Mod. & LARS & Meas. & Mod. & LARS & Rep. & Mod. \\
\hline St. Johann & $0.9-0.9$ & $1.0-5.0$ & 0.88 & 0.82 & 0.86 & 0.86 & 125 & 127 & 126 & 380 & 381 & 465 & 119 & 120 \\
\hline Innsbruck & $1.0-3.0$ & $1.0-5.3$ & 0.85 & 0.81 & 0.82 & 0.95 & 62 & 60 & 57 & 109 & 105 & 134 & 138 & 137 \\
\hline Gerlos & $0.1-2.5$ & $1.0-5.8$ & 0.62 & 0.86 & 0.81 & 0.72 & 155 & 155 & 154 & 466 & 448 & 472 & 122 & 123 \\
\hline
\end{tabular}


Table 6. Climate change signals (Nov-Apr) at the 3 ski areas (see Table 1) for two climate change scenarios (B1; A1B)

\begin{tabular}{|lcccc|}
\hline $\begin{array}{l}\text { Time } \\
\text { period }\end{array}$ & $\begin{array}{c}\text { Ski } \\
\text { area }\end{array}$ & $\begin{array}{c}\text { Temperature } \\
\left({ }^{\circ} \mathrm{C}\right)\end{array}$ & $\begin{array}{c}\text { Precipitation } \\
(\%)\end{array}$ & $\begin{array}{c}\text { Snow } \\
\text { days }\end{array}$ \\
\hline $2030 \mathrm{~s}$ & $\mathrm{~A}$ & $0.8 ; 1.1$ & $15 ; 10$ & $-10 ;-24$ \\
& $\mathrm{~B}$ & $0.8 ; 1.1$ & $14 ; 10$ & $-23 ;-28$ \\
& $\mathrm{C}$ & $0.8 ; 1.0$ & $11 ; 8$ & $-8 ;-7$ \\
$2050 \mathrm{~s}$ & $\mathrm{~A}$ & $1.5 ; 2.4$ & $7 ; 9$ & $-39 ;-59$ \\
& $\mathrm{~B}$ & $1.6 ; 2.5$ & $8 ; 13$ & $-37 ;-41$ \\
& $\mathrm{C}$ & $1.4 ; 2.2$ & $4 ; 4$ & $-21 ;-37$ \\
$2080 \mathrm{~s}$ & $\mathrm{~A}$ & $2.7 ; 4.3$ & $9 ; 9$ & $-74 ;-114$ \\
& $\mathrm{~B}$ & $2.8 ; 4.3$ & $10 ; 15$ & $-45 ;-47$ \\
& $\mathrm{C}$ & $2.7 ; 4.2$ & $4 ; 0$ & $-36 ;-93$ \\
\hline
\end{tabular}

area B is currently not naturally snow reliable. Comparatively high temperatures owing to frequent Foehn events (warm downslope winds, 49 'Foehn' days per year in Innsbruck), together with relatively dry conditions, are the reason for the small number of skiable days with natural snow. With snowmaking, 100 operation days can be ensured until the 2040s to the 2060s. Short-term losses are 1-4\%, medium-term losses are $10-29 \%$ and long-term losses are $60-99 \%$. Ski area C is naturally snow reliable until the 2060s (A1B) and the end of the century in the B1 scenario. Snowmaking could ensure a sufficiently long season for the entire 21 st century in both scenarios. Short-term losses are $1-3 \%$, medium-term losses are $5-8 \%$ and long-term losses are $8-22 \%$.

Skiable days are lost first in the early season, followed by Christmas and the off-season (Table 7). Gains in the off-season in the 2030s and 2050s can be explained by increased precipitation through the winter season and more technically produced snow to ensure operation in the Christmas period, together with a still moderate temperature increase. Although ski area managers stated that operation days in the early season are of minor importance from a financial point of view, being operable some weeks before Christmas is nevertheless important from a marketing perspective. If skiing conditions are not sufficient during that period, guests tend to book hesitantly and season pass sales are reduced. Lost skiable days in the Christmas holidays might damage the reputation of the destinations. Considering that $\sim 30 \%$ of winter revenues are generated during these $2 \mathrm{wk}$, even slight losses of skiable days have a potentially high financial impact. Potential losses in this period are projected for the 2050s onwards at the mean altitudes of ski areas A and B and the 2080s (A1B) at ski area C.

Although these results for the mean altitude are valuable for comparison with existing studies (e.g. Scott et al. 2003, 2008, Abegg et al. 2007), a more detailed analysis is necessary and can be provided by SkiSim 2.0 to assess changes that are potentially relevant for demand. As ski area size is a very important selection criterion for skiers (MANOVA 2010), the size of the ski area in operation at least for $100 \mathrm{~d}$ was analyzed.

Currently, $100 \%$ of the skiing terrain is snow reliable with snowmaking at ski areas $\mathrm{A}$ and $\mathrm{C}$ and $85 \%$ at ski area B (Fig. 6). Little changes are projected for ski area A until the 2030s to the 2040s, with great impacts thereafter. At ski area $\mathrm{B}$, a continuous decrease is projected for the 21st century, with no snow-reliable skiing terrain left in the 2080s. Ski area C is able to open $100 \%$ of its ski slopes until the 2060 s to the 2080 s. In the interviews, ski area managers were asked what share of closed skiing terrain would be (1) without

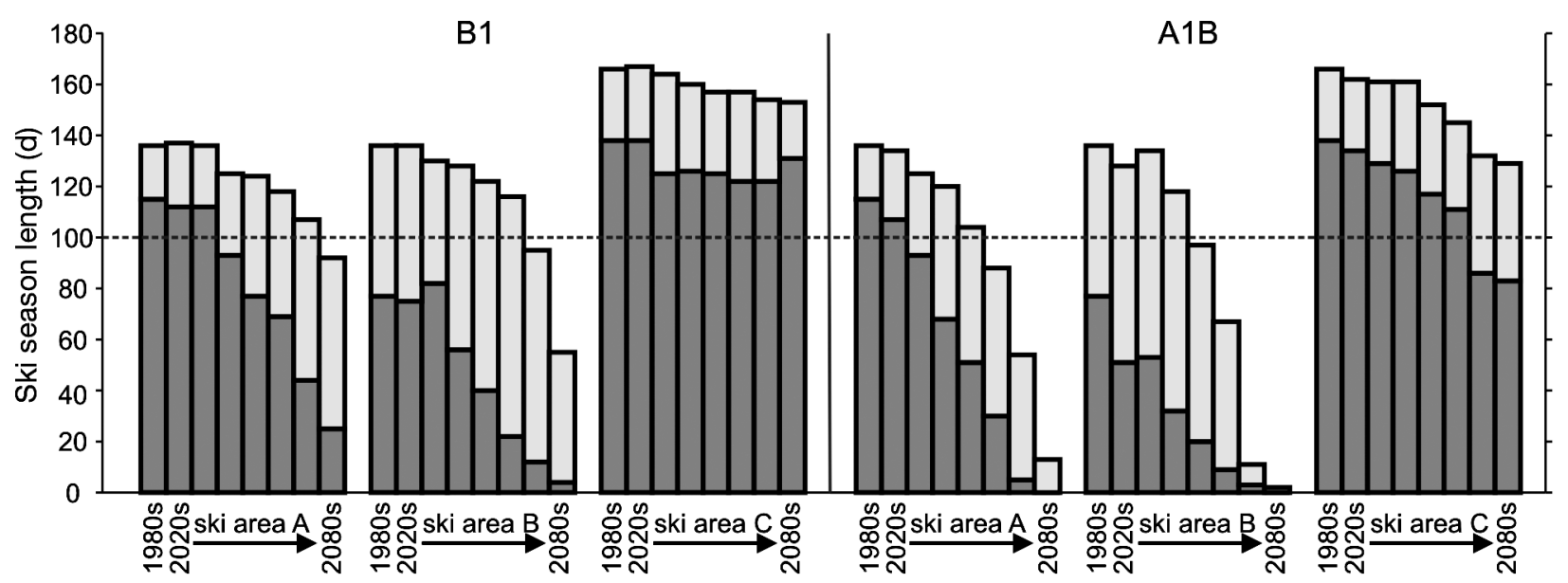

Fig. 5. Projected ski season lengths at mean altitude with natural (dark grey) and machine-made (light grey) snow under the B1 and A1B climate change scenarios. Data are the number of days with snow depth $\geq 30 \mathrm{~cm}$. Dashed line is the $100 \mathrm{~d}$ snow reliability threshold 
Table 7. Projected skiable days of each season period at the mean altitude, with snowmaking

\begin{tabular}{|c|c|c|c|c|c|c|c|}
\hline \multirow{2}{*}{ Ski area } & \multirow{2}{*}{ Scenario } & \multicolumn{6}{|c|}{ - Season periods } \\
\hline & & $1 \mathrm{Nov}-21 \mathrm{Dec}$ & 22 Dec-4 Jan & 5 Jan-8 Feb & 9 Feb-1 Mar & 2-31 Mar & 1-30 Apr \\
\hline \multirow[t]{7}{*}{ St. Johann (A) } & Baseline & 17 & 14 & 35 & 21 & 30 & 19 \\
\hline & 2030 B1 & 14 & 14 & 35 & 21 & 30 & 22 \\
\hline & $2030 \mathrm{~A} 1 \mathrm{~B}$ & 8 & 14 & 35 & 21 & 30 & 17 \\
\hline & 2050 B1 & 8 & 12 & 35 & 21 & 30 & 18 \\
\hline & $2050 \mathrm{~A} 1 \mathrm{~B}$ & 4 & 11 & 35 & 21 & 29 & 3 \\
\hline & 2080 B1 & 2 & 8 & 33 & 21 & 26 & 2 \\
\hline & 2080 A1B & 0 & 0 & 7 & 5 & 0 & 0 \\
\hline \multirow[t]{7}{*}{ Patscherkofel (B) } & Baseline & 17 & 14 & 35 & 21 & 30 & 19 \\
\hline & 2030 B1 & 11 & 13 & 34 & 21 & 30 & 22 \\
\hline & 2030 A1B & 7 & 13 & 35 & 21 & 30 & 28 \\
\hline & 2050 B1 & 3 & 10 & 33 & 21 & 30 & 25 \\
\hline & 2050 A1B & 3 & 8 & 32 & 21 & 27 & 6 \\
\hline & 2080 B1 & 0 & 3 & 14 & 14 & 21 & 2 \\
\hline & 2080 A1B & 0 & 0 & 0 & 1 & 1 & 0 \\
\hline \multirow[t]{7}{*}{ Zillertal Arena (C) } & Baseline & 36 & 14 & 35 & 21 & 30 & 30 \\
\hline & 2030 B1 & 34 & 14 & 35 & 21 & 30 & 30 \\
\hline & $2030 \mathrm{~A} 1 \mathrm{~B}$ & 31 & 14 & 35 & 21 & 30 & 30 \\
\hline & 2050 B1 & 28 & 14 & 35 & 21 & 30 & 30 \\
\hline & $2050 \mathrm{~A} 1 \mathrm{~B}$ & 32 & 14 & 35 & 21 & 30 & 29 \\
\hline & 2080 B1 & 26 & 14 & 35 & 21 & 30 & 27 \\
\hline & 2080 A1B & 7 & 10 & 35 & 21 & 30 & 27 \\
\hline \multicolumn{2}{|c|}{$\begin{array}{l}\% \text { of revenues in Tyrol } \\
\text { (mean } 2003 / 2004-2005 / 2006 \text { ) }\end{array}$} & 5 & 30 & 13 & 30 & 15 & 7 \\
\hline
\end{tabular}

impact on demand, (2) with medium impact, and (3) virtually a catastrophe. It is difficult to define uniform thresholds, because it depends on the type of the ski area-isolated ski area versus large interconnected ski areas-and the ratio of day trippers (more sensitive) and holiday guests (less sensitive) in the ski area. In large ski areas, the connections between the different parts are very crucial, with high-demand losses if areas are closed. In smaller, isolated ski areas, the valley run is of great importance, with up to $50 \%$ fewer skiers if closed. Apart from that, $80 \%$ of open skiing terrain was named as threshold for minor impacts and $50 \%$ for major but still acceptable losses in both types of ski areas. As ski areas A and B are rather small and are thus dependent on open valley runs, already small changes in snow-reliable skiing terrain might cause substantial problems, as the lower runs are the most and first affected (Fig. 6). At ski area A, the valley run is projected to be snow reliable until the 2040s. The $80 \%$ threshold is met until the 2030 s to the 2040 s, and the $50 \%$ threshold until the 2040s to the 2060s. At ski area $B$, the thresholds are exceeded only in the baseline $(80 \%)$ and until the 2040 s to the 2060 s (50\%). The entire terrain of ski area $\mathrm{C}$ remains snow reliable until the 2080s in the B1 scenario and both thresholds are exceeded in all decades of the 21st century in the A1B scenario.

\subsection{Impact on snowmaking requirements}

The weighted average of snow production in the baseline is $45 \mathrm{~cm}$ at ski area A. Snow production at ski area B is higher $(54 \mathrm{~cm})$, owing to warmer and drier conditions, and is lowest at the high-altitude ski area $\mathrm{C}$ $(31 \mathrm{~cm})$. To reach the projected season lengths, the amount of technically produced snow needs to be increased at all ski areas (Fig. 7). The maximum snow production marking the current limits of snowmaking technology are reached in the 2050s (A1B, +69\%) to the 2070s $(\mathrm{B} 1,+78 \%)$ at ski area $\mathrm{A}$, in the $2030 \mathrm{~s}$ $(+14 \%)$ to the $2050 \mathrm{~s}(+15 \%)$ at ski area $\mathrm{B}$ and in the 2080 s at ski area $C(+16$ to $+112 \%)$. Water demand would be increased by the same amounts, requiring more snowmaking ponds with potential negative impacts on landscape aesthetics and conflicts of interest. As the energy efficiency of current snowmaking technology decreases with rising temperaturesproducing snow near the temperature limit requires about 6 times the energy than producing at optimal temperatures (Teich et al. 2007) - the potential increase in energy consumption is considerably higher than the increase in water demand.

Assuming the use of a temperature-independent technology, a total increase in snow production of $167-$ $330 \%$ would be necessary at ski area A and 122-223\% 


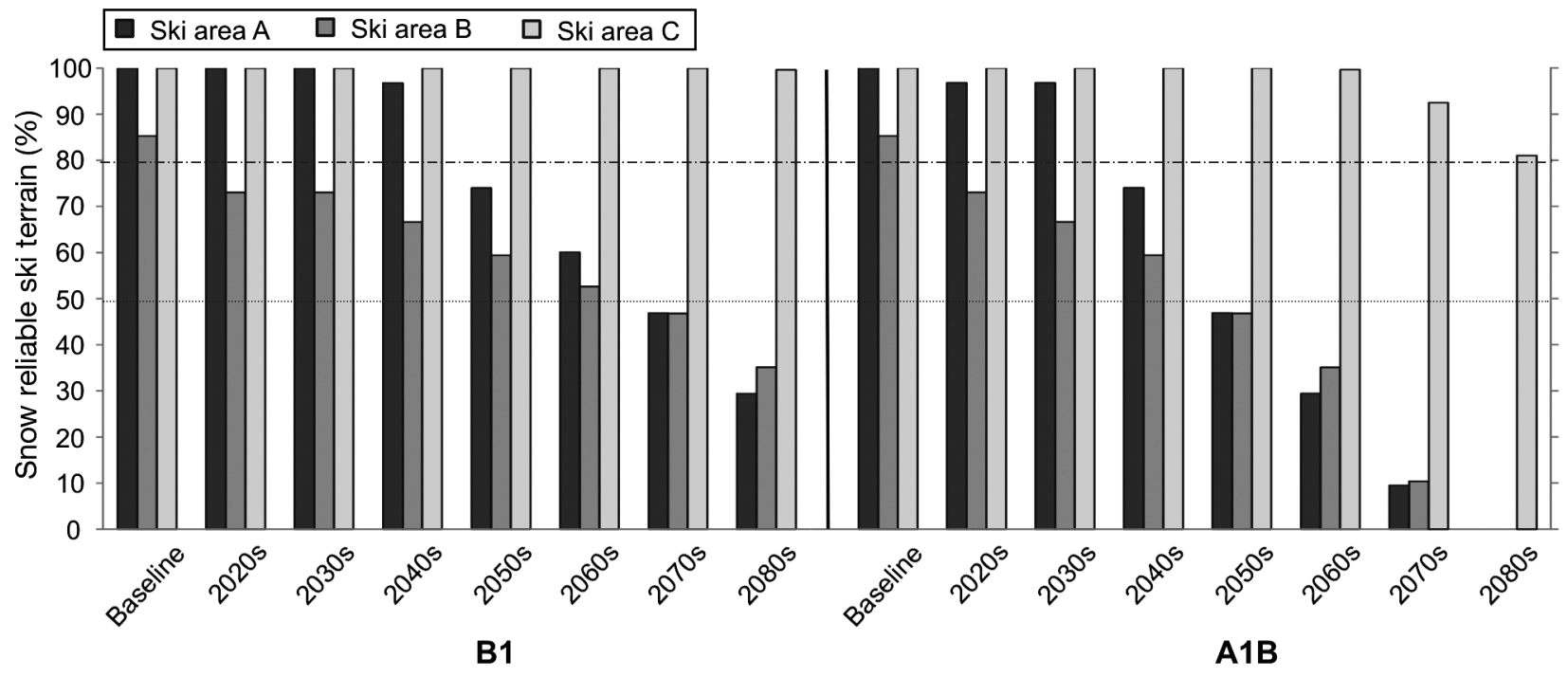

Fig. 6. Portion of ski terrain that is operable for at least $100 \mathrm{~d}$ with snowmaking under the B1 and A1B climate change scenarios. Lines mark the thresholds of open skiing terrain negatively affecting demand, with almost no impact above the dot-dashed line and high impact below the dotted line

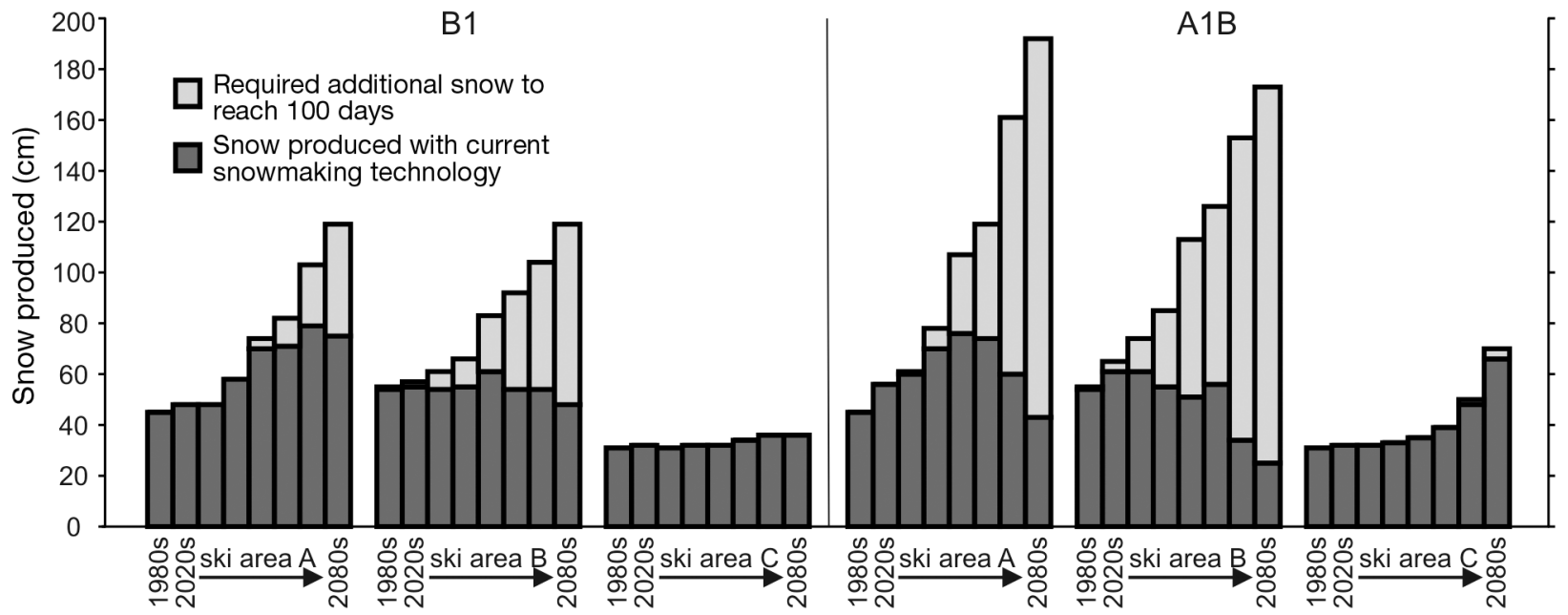

Fig. 7. Projected snow production as a weighted average of all altitudinal bands under the B1 and A1B climate change scenarios

at ski area B to ensure a $100 \mathrm{~d}$ season until the end of the century. Ski area C could produce most of the snow with current snowmaking technology, except at the lowest runs, resulting in a slightly higher increase of $16-124 \%$. Again, the analogous increase in water demand is likely to provoke conflicts and energy consumption must be seen very critical in terms of climate change mitigation and aspects of sustainability.

\section{DISCUSSION AND CONCLUSIONS}

The results of the validation process suggest that SkiSim 2.0 is an appropriate tool to simulate ski season lengths and snowmaking requirements at different alti- tudes and in different climatic subregions of the study area. Nevertheless, some limitations of the model have to be considered. The calibration of the snowfall transition temperature is crucial, as potential measurement errors may influence the accuracy of snowfall temperature and fresh snow density is not only dependent on temperature but also on wind. Warm winds also have a reinforcing effect on melt, so melt might be underestimated under such conditions. Aspect is not considered in the model, resulting in an underestimation of melt on south-facing slopes and an overestimation on north-facing slopes. The degree-day factor represents empirical relationships between multiple parameters of the energy balance determined for the baseline climate. It is not assured that these relationships will remain unchanged with climate 
change. The climate model is afflicted with uncertainties as well. In winter (Dec-Feb), REMO is warmer and wetter than the ensemble mean of the PRUDENCE experiments. The greatest source of uncertainty for winter temperature projections in the Alps can be related to the GCM, followed by the emissions scenario, whereas for winter precipitation it is the GCM, followed by the RCM (Déqué et al. 2007). Thus, it would be valuable to use several RCMs with different GCMs as drivers to get a greater range of possible futures and to be able to assess potential uncertainties.

The results of the impact assessment show that potential impacts on ski season length are considerably less when incorporating snowmaking (Fig. 5), which is in agreement with the findings of Scott et al. (2003). Although Breiling et al. (1997) expected strong impacts for the 2020s for the Kitzbuehel area (this includes ski area A) without snowmaking, similar to the SkiSim 2.0 results without snowmaking, ski area A is projected to be snow reliable until the 2050s to the 2070 s with snowmaking. The analysis of skiable days at 52 climate stations in Tyrol, as well as model results with and without snowmaking, revealed that smallscale climate characteristics need to be considered. Ski area A has a higher snow reliability rating than ski area $B$, although the latter is at higher altitude (by $400 \mathrm{~m}$ ). A comparison with Abegg et al. (2007) shows that, using the spatially coarsely defined altitudinal thresholds, the snow reliability may be underestimated (ski area A being below the current $1200 \mathrm{~m}$ snow reliability line) as well as overestimated (ski area B was assumed to be naturally snow reliable in a $2^{\circ} \mathrm{C}$ scenario). Thus, the chosen ski areas are also not representative for low-, mid- and high-altitude ski areas. A comprehensive analysis of all ski areas in the study area is necessary to assess the vulnerability of ski tourism in Tyrol.

Comparing SkiSim 2.0 model results with SkiSim 1.0 model projections for Québec (Scott et al. 2007), very similar relative losses of ski season length can be found. However, simulated losses in the core season (Christmas holidays to March) are greater for ski areas $A$ and $B$ than for the ski areas analysed in Scott et al. (2007). Considering that projected temperature changes $\left(1.4-2.3^{\circ} \mathrm{C}\right.$ for the 2020 s and $2.8-7.9^{\circ} \mathrm{C}$ for the 2050s) are greater than for Tyrol, the relative vulnerability of the ski tourism industry to climatic changes appears to be greater in Tyrol than in Québec, resulting in less competitiveness in the future.

Interviews with ski area managers indicated that, when analysing individual ski businesses, the type and characteristics of a ski area are further relevant factors influencing their vulnerability. Thus, looking at potential losses of skiing terrain may be of additional value for future climate change impact assessments.
The limits of current snowmaking technology are reached in the 2030s (ski area B) to the 2050s (ski area A). By then, the projected increase of snow production of up to $112 \%$, together with less skiable days, poses a challenge for a profitable ski business. Ski area managers stated that, currently, $10-20 \%$ of the turnover is spent for snowmaking, with higher values in low elevated ski areas with extensive snowmaking and lower values in high-altitude ski areas. It was also mentioned that further significant increases in snow production will inevitably cause higher lift ticket prices, with a resultant negative impact on demand. Seen from this angle, temperature-independent snow production-with projected increases of up to $330 \%$ to remain snow reliable until the end of the century-is unlikely to be a sustainable future adaptation strategy. Above all, considering that the reputation of a ski area might be damaged as soon as skiable days in the Christmas period are lost or as crucial parts of the ski area (e.g. valley-run, connection to another ski area) must be abandoned, the vulnerability of low- and midaltitude ski areas is high.

Climate change is likely to destabilize the winter tourism system in the next decades. But, as several other factors influence supply and demand, the system's resilience could be strengthened or weakened. The economic limits of snowmaking are still poorly understood. Potential increases in energy prices owing to higher taxes and/or shortage of fossil fuel would affect the profitability of snowmaking. A higher frequency of snow-scarce winters is likely to influence the decision-making processes of skiers. Thus, a deeper understanding of the winter tourism system, considering more driving factors, their interdependencies and potential positive and negative feedbacks, would be helpful to better assess the vulnerability of winter destinations.

Acknowledgements. The author is grateful to the Austrian science fund (FWF) for financing the project, D. Scott for his support and for insight into the SkiSim 1.0 model, A. Matzarakis for the processing of climate scenario data provided by the DKRZ, K. Förster for data organization and programming issues and H. Stötter for supervision. Thanks also to J. Dawson and B. Abegg for comments on an early draft of the paper.

\section{LITERATURE CITED}

Abegg B (1996) Klimaänderung und Tourismus. Klimafolgenforschung am Beispiel des Wintertourismus in den Schweizer Alpen. vdf Zurich, Zurich

Abegg B, Agrawala S, Crick F, de Montfalcon A (2007) Climate change impacts and adaptation in winter tourism. In: Agrawala S (ed) Climate change in the European Alps. Adapting winter tourism and natural hazards management. OECD, Paris, p 25-60

Becken S, Hay JE (2007) Tourism and climate change. Risks 
and opportunities. Channel View Publications, Clevedon Braun LN, Aellen M (1990) Modelling discharge of glacierized basins assisted by direct measurements of glacier mass balance. In: Lang $H$, Musy A (eds) Hydrological measurements. The water cycle. Hydrology in mountainous regions, Vol 1.: IAHS Publications, Wallingford, p 99-106

Breiling M, Charamza P, Skage OR (1997) Klimasensibilität österreichischer Bezirke mit besonderer Berücksichtigung des Wintertourismus. Institut für Landschaftsplanung Alnarp, Schwedische Universität für Agrarwissenschaften (Forschungsauftrag des Österreichischen Bundesministerium für Wirtschaftliche Angelegenheiten/Abteilung Tourismuspolitik und des Österreichischen Bundesministerium für Umwelt), Alnarp

Brooks K, Ffolliott P, Gregersen H, DeBano L (2003) Hydrology and the management of watersheds, 3rd edn. Iowa State Press, Ames, IA

Christensen JH, Christensen OB (2007) A summary of the PRUDENCE model projections of changes in European climate by the end of this century. Clim Change 81:7-30

Déqué M, Rowell DP, Lüthi D, Giorgi F and others (2007) An intercomparison of regional climate simulations for Europe: assessing uncertainties in model projections. Clim Change 81:53-70

Fauve M, Rhyner H, Schneebeli M (2002) Pistenpräparation und Pistenpflege. Das Handbuch für den Praktiker. SLF, Davos

Fliri F (1975) Das Klima der Alpen im Raume von Tirol. Universitätsverlag Wagner, Innsbruck

Hantel M, Hirtl-Wielke LM (2007) Sensitivity of alpine snow cover to European temperature. Int J Climatol 27: $1265-1275$

Hennessy K, Whetton P, Smith I, Bathols J, Hutchinson M, Sharples J (2003) The impact of climate change on snow conditions in mainland Australia. CSIRO Marine and Atmospheric Research, Hobart, available at www.cmar. csiro.au/e-print/open/hennessy_2003a.pdf

Kustas W, Rango A, Uijlenhoet R (1994) A simple energy budget algorithm for the snowmelt runoff model. Water Resour Res 30:1515-1527

Laternser M, Schneebeli M (2003) Long-term snow climate trends of the Swiss Alps (1931-99). Int J Climatol 23: $733-750$

López-Moreno JI, Goyette S, Beniston M (2009) Impact of climate change on snowpack in the Pyrenees: horizontal spatial variability and vertical gradients. J Hydrol 374: 384-396

MANOVA (2009) Wirtschaftsbericht der Seilbahnen. MANOVA NetBusiness Solutions, Vienna, available at www.seilbahnen.at/presse/wirtschaftsdaten/files/berichts blaetter_tm_winter0708.pdf

Editorial responsibility: Nils Chr. Stenseth, Oslo, Norway
MANOVA (2010) Skifahrerpotentiale in Europa. MANOVA, Vienna, available atwww.seilbahn.net/snn/konfig/uploads/ pdf/239.pdf

Martinec J (1960) The degree-day factor for snowmelt-runoff forecasting. IAHS Pub 51:468-477

Marty C (2008) Regime shift of snow days in Switzerland. Geophys Res Lett 35:L12501 doi:10.1029/2008GL033998

Meister R (1986) Density of new snow and its dependence on air temperature and wind. Zürcher Geographische Schriften 23:73-79

Scherrer S, Appenzeller C (2006) Swiss Alpine snow pack variability: major patterns and links to local climate and large-scale flow. Clim Res 32:187-199

> Scherrer S, Appenzeller C, Laternser M (2004) Trends in Swiss Alpine snow days: the role of local- and large-scale climate variability. Geophys Res Lett 31:L13215 doi: 10.1029/2004GL020255

Scott D (2006) Global environmental change and mountain tourism. In: Gössling S, Hall MC (eds) Tourism and global environmental change. Routledge, London, p 54-75

Scott D, McBoyle G, Mills B (2003) Climate change and the skiing industry in southern Ontario (Canada): exploring the importance of snowmaking as a technical adaptation. Clim Res 23:171-181

Scott D, McBoyle G, Minogue A (2007) Climate change and Quebec's ski industry. Glob Environ Change 17:181-190

Scott D, Dawson J, Jones B (2008) Climate change vulnerability of the US Northeast winter recreation-tourism sector. Mitig Adapt Strategies Glob Change 13:577-596

Semenov M, Barrow E (1997) Use of a stochastic weather generator in the development of climate change scenarios. Clim Change 35:397-414

Semenov M, Stratonovitch P (2010) Use of multi-model ensembles from global climate models for assessment of climate change impacts. Clim Res 41:1-14

Steiger R (2007) Der Klimawandel und seine Auswirkungen auf die Skigebiete im bayerischen Alpenraum. SalzwasserVerlag, Bremen

Steiger R, Mayer M (2008) Snowmaking and climate change. Future options for snow production in Tyrolean ski resorts. Mt Res Dev 28:292-298

Teich M, Lardelli C, Bebi P, Gallati D and others (2007) Klimawandel und Wintertourismus: Ökonomische und ökologische Auswirkungen von technischer Beschneiung. SLF/ WSL, Birmensdorf/Davos

Tirol Werbung (2010) Tirol in Zahlen. Available at www. presse.tirol.at/xxl/de/tirol-zahlen/

UNWTO (United Nations World Tourism Organisation) (2007) Davos Declaration. WMO, Paris

Wolfsegger C, Gössling S, Scott D (2008) Climate change risk appraisal in the Austrian ski industry. Tourism Rev Int 12: $13-23$

Submitted: February 9, 2010; Accepted: September 26, 2010 Proofs received from author(s): November 8, 2010 